\title{
Synanthropic flora of Kuzbass
}

\author{
S.A. Sheremetova ${ }^{1,2,{ }^{*}, \text { S.N. Vityaz }}{ }^{1}$, E.B. Rotkina ${ }^{1}$, and S.I. Mikhailova ${ }^{3,4}$ \\ ${ }^{1}$ Kuzbass State Agricultural Academy, Kemerovo, Russia \\ ${ }^{2}$ Federal Research Center of Coal and Coal Chemistry SB RAS, Kemerovo, Russia \\ ${ }^{3}$ Tomsk branch of the FSBU All-Russian Plant Quarantine Center, Tomsk, Russia \\ ${ }^{4}$ National Research Tomsk State University, Tomsk, Russia
}

\begin{abstract}
The article presents the materials of studies of the adventive flora of the Kemerovo region. For the territory of the Kemerovo region, we identified 244 alien species belonging to 162 genera and 50 families. As a result of the increasing process of invasion of new species into the territory of the region, the need for constant monitoring of alien species for the degree of their naturalization, especially in natural cenoses, is urgent. The problem of synanthropic plant species is becoming increasingly important not only for economically developed territories, but also for the relatively preserved mountain regions of Kuzbass. As a result of the studies, it was found that the synanthropic fraction of the Kuzbass flora, consisting of adventive and apophyte species, accounts for about $18 \%$ of the total composition of the flora of vascular plants in the Kemerovo region (60 apophyte species, $244-$ advent ones). The revealed heterogeneity in the chorological, ecological and biological terms of the species of the adventive fraction makes it possible to find suitable conditions in various types of ecotopes on the territory of the Kemerovo region. This type of work can serve as a basis for developing a strategy for the preservation of natural phytosystems of Kuzbass.
\end{abstract}

\section{Introduction}

Currently, the agro-industrial complex of the Kemerovo region is the most important sector of the regional economy, along with the main industrial complexes [10, p. 19]. According to the Passport of the Kemerovo Region - Kuzbass, in 2019, a little more than 14\% (394 thousand people) of the population live in rural areas, and only $2.4 \%$ (29 thousand people) live in agriculture [10]. In the agricultural turnover there are 2651.3 thousand hectares of agricultural land, which is $27.7 \%$ of the total area of land resources of the Kemerovo region [1, p. 156]. In addition, the territory of the region belongs to areas with a high degree of soil disturbance, including as a result of plowing up areas suitable for this. This is facilitated by the high fertility of the soil and the needs of the region for crop production. In the XX century, when, along with the growing agricultural development of the country, there was a rapid development of coal enterprises, which led to the complete destruction of vegetation in large areas.

In 1950 A.V. Kuminova [5] pointed out that the most favorable natural conditions for agricultural production are in the central steppe and forest-steppe regions of the Kemerovo

\footnotetext{
* Corresponding author: ssheremetova@rambler.ru
} 
region. Due to the ruggedness of the terrain, heterogeneous soil cover, they are concentrated in the Kuznetsk depression and the forest-steppe strip running along the northeastern end of the Kuznetsk Alatau.

Since the end of the $80 \mathrm{~s}$, the changes that began in the country, which led to privatization and the collapse of the collective economy, as a result of which the regional economy, like the economy of the entire country, entered a state of deep systemic crisis. As a result, a large number of abandoned agricultural lands was formed, and young birch forests were gradually formed on empty fields.

At the moment, the Kemerovo region - Kuzbass, is one of the most industrially developed and densely populated areas in the south of Western Siberia. The leading industries are coal and metallurgy. The extraction of minerals in the Kuznetsk coal basin is carried out not only by the mine, but also by the open method, as a result, the problem of lands disturbed by dumps arises. According to the Report "On the State of the Environment...", more than a billion tons of rock are extracted and stored on the surface every year. Thereof, the adjacent territories undergo strong and sometimes irreversible anthropogenic changes in the soil cover, animal and vegetation cover [1, p. 345]. In the process of such anthropogenic transformation, the indigenous flora of the Kemerovo region lost some of its species, while the invasion of adventive species took place [21].

All this ultimately led to the fact that some of the species of native flora adapt to living in changed conditions: arable land, fields, fallow lands, roadsides, railway embankments, landfills, etc.

Synanthropic plants in the flora of the Kemerovo region are of undoubted interest for study in light of the indicated problems, the constantly increasing anthropogenic pressure on natural ecosystems. The Kuznetsk Basin of the Kemerovo Region is a territory significant for the conservation of biological diversity in the Altai-Sayan region [3].

\section{Materials and methods}

The study area is located in the southeast of Western Siberia and is located in temperate latitudes between $52^{\circ} 08^{\prime}$ and $57^{\circ} 54^{\prime}$ north latitude and $83^{\circ} 13^{\prime}$ and $89^{\circ} 28^{\prime}$ east longitude, with a total area of 95.7 thousand $\mathrm{km} 2$. Located at the junction of the West Siberian Plain and the mountains of South Siberia, most of the Kemerovo region belongs to the KuznetskSalair geomorphological province of the northwestern part of the Altai-Sayan mountainous region [5], which affects the distribution of the main types of vegetation. The mountain ranges of the Salair Ridge, Gornaya Shoria and Kuznetsk Alatau disturb the general distribution of the vegetation cover according to latitudinal zoning, making it possible to develop taiga formations at the geographical latitude of the forest-steppe and steppe zones of Western Siberia.

The first scientific information about the flora of the Kemerovo region dates back to 1721 and is associated with the name of D.G. Messerschmidt. He crossed the territory of Kuzbass from Tomsk to Kuznetsk and through the Kuznetsk Alatau proceeded to Abakan [4, p. 134]. Subsequently, the materials collected by Messerschmidt in the second half of the 18th century were used by I.G. Gmelin, P.S. Pallas when publishing works on the flora of Siberia and Russia. The study of the flora of the Kemerovo region by the authors of the article has been conducted since 2000, since the opening of the Kuzbass Botanical Garden. In general, the summary of the flora of the study area includes 1,700 species of higher vascular plants [9; $15]$.

The synanthropic flora of the Kemerovo region was identified according to the data of long-term (2000-2020) field studies, taking into account information on weeds [8; 20, p. 43] and adventive $[14 ; 13 ; 16]$ plants, the samples are kept in the funds of the KUZ Herbarium. 


\section{Results and discussion}

In the flora of Kuzbass, there are 60 apophytic species, which are subdivided, depending on the place of growth, into segetal - species growing in arable lands and agrocenoses: Cirsium incanum (S.G. Gmel.) Fisch., Cirsium setosum (Willd.) Besser, Cirsium vulgare (Savi) Ten., Convolvulus arvensis L., Sagina procumbens L., Stellaria media (L.) Vill., Sonchus arvensis L. and ruderal plants that prefer to grow near dwellings, garbage dumps, wastelands, along roads: Capsella bursa-pastoris (L.) Medikus, Descurainia sophia (L.) Webb ex Prantl, Polygonum aviculare L., Potentilla anserine L., Potentilla norvegica L., Psammophiliella muralis (L.) Ikonn. etc.

The maximum number of synanthropic species are noted in settlements and their environs. For the reasons described above, the leader in the representation of synanthropic species in the region is the Kuznetsk Basin. Since ancient times, these territories have been used as agricultural land, and now over $50 \%$ of all the region's land are allotted for arable land $[1$, p. 170].

In the course of the study, for the territory of the Kemerovo region, we identified 244 adventive species belonging to 162 genera and 50 families. The most impressive in terms of number of species is the Asteraceae family ( 46 species), followed by Poaceae (26 species), Brassicaceae (24 species), Fabaceae (18 species), Lamiacee (15 species) and Caryophyllaceae (12 species). The next group of families contains from 8 to 5 species: Rosaceae (8), Boraginaceae (7), Malvaceae (7), Scroplulariaceae (6) Solanaceae (5) Amaranthaceae (5), Onagraceae (5). From 4 to 2 adventive species include 10 families, 25 families - 1 species each.

The expansion of alien plants is gradually leading to the floristic pollution of the territory and is becoming a global environmental problem. As a result of this process, together with adventive species, new families are noted in the flora of Kuzbass: Aceraceae, Amaranthacea, Commelinaceae, Cucurbitaceae, Elaeagnaceae, Oleacae, Resedaceae, Ulmaceae, Zygophyllaceae and, accordingly, new genera (50 in total):

Acer, Alcea, Abutilon, Acalypha, Amelanchier, Anthyllis, Cannabis, Commelina, Conium, Daucus, Elaeagnus, Hippophaë, Hibiscus, Galega, Lupinus, Malus, Oenothera, Reseda, Sorbaria, Tribulus, Ulmus, Xanthoxalis, etc.

It should be noted that, despite certain changes in natural vegetation, they affect the entire territory of the Kemerovo region, but to the least extent, to date, the transformation processes have affected the mountainous regions of the Kuznetsk Alatau and Gornaya Shoria.

In the works of many authors, adventive species are classified according to three main separate criteria: the mode of immigration, the time of introduction and the degree of naturalization $[8 ; 17 ; 18]$.

In Kuzbass, according to the time of introduction, it possible to distinguish 3 groups of species of the adventive fraction of flora:

Eukenophytes include 162 species. This is the largest group in terms of the number of species, the maximum number of alien species was recorded in the Kuzbass in the XX century. The active agricultural development of the Kemerovo region, the development of summer cottages, the construction of roads and, accordingly, the growth of traffic flows contributed to the introduction of such species as: Aconogonon divaricatum (L.) Nakai ex Mor, genus Amelanchier, Arctium minus (Hill) Bernh., Aster novi-belgii L., Calendula officinalis L., Epilobium adenocaulon Hausskn., Lotus corniculatus L., Matricaria recutita L., Oenothera biennis L., Xanthium strumarium L. It should be noted that the growth of invasions continues, and further penetration of other species into Kuzbass can be expected.

The species, that appeared in the XIX century on the territory of the Kemerovo region, belong to the group of kenophytes - 19 species. These are such weed-field and ruderal species as representatives of the genus Chenopodium, Asperugo procumbens L., Acinos arvensis 
(Lam.) Dandy, Cichorium intybus L., Camelina sativa (L.) Crantz, and also traditionally cultivated in the farmsteads of Armoracia rusticana P.G. Gaertn., B. Mey. \& Scherb. This group is so small in number due to the impossibility of determining the time of introduction of many species into the territory of Kuzbass.

The most ancient group - archaeophytes, also includes 19 species. These are species both deliberately introduced by humans: Avena sativa L., Cannabis sativa L., Neslia paniculata (L.) Desv., Panicum miliaceum L., and weed-field species accompanying cultivated plants: Atriplex patula L., Bunias orientalis L., Echinochloa crus-galli (L.) P. Beauv., Lepidium ruderale L. etc. Scientists believe that for the territory of the Kemerovo region, the construction of the Siberian tract and the activities of the Russian-American company served as the main frontier for the penetration of archaeophytes, which contributed to the migration of species to Siberia from the Far East (Ermolaev, 2013).

The classification of the advents by the method of introduction shows that for some species at the present time we cannot determine the scenario of their appearance on the territory of the region, this is a group of xenoergaziophytes: Amaranthus cruentus L., Echinocystis lobata (Michx.) Torr. \& A. Gray, Lolium perenne L., there are 9 species in total. Ergasiophyta species - 67 species, introduced into the territory of the region intentionally as decorative, food, etc. intentionally: genus Amelanchier, Berberis vulgaris L., Eschscholzia californica Cham., Portulaca grandiflora Hook., etc. The third, the most numerous group of xenophytes is 168 species. It includes, as a rule, weeds introduced by chance, together with cultivated species or traffic flows with various cargoes: Agrostemma githago L., Vaccaria hispanica (Mill.) Rauschert, виды родов Amaranthus, Atriplex, Chenopodium, etc.

The degree of naturalization of the species of immigrants is very different, but against the general background of Advent, growing mainly in disturbed habitats, a group of the most aggressive species, agriophytes, stands out. These species are capable of being part of natural phytocenoses in the Kemerovo region. Currently, there are relatively few such species - about 10: Amoria hybrida (L.) C. Presl, Armoracia rusticana P.G. Gaertn., Malus baccata (L.) Borkh., Medicago sativa L., Calystegia spectabilis (Brummitt) N.N.Tzvelev, Saponaria officinalis L.. The most aggressive of them require the closest attention, to which we can classify 3 species on the territory of Kuzbass: Acer negundo L., Solidago canadensis L., Elodea canadensis Michx. Colonophytes are a group of plants that have entrenched themselves in places of drift or run wild, but currently do not spread further and do not penetrate into natural communities. In Kuzbass, scientists classify about 30 species as colonophytes: Aconogonon divaricatum (L.) Nakai ex Mori, Acer tataricum L., Padus maackii (Rupr.) Kom., Panicum miliaceum L. Papaver rhoeas L. Pastinaca sativa L., Tilia cordata Mill., Helianthus tuberosus L., Viola arvensis Murray, species of the genera Oenothera and Xanthium, etc.

The third group in terms of the degree of naturalization is epecophytes, species that spread over disturbed habitats and penetrate only segetal or ruderal communities. This largest group includes 196 species: Amelanchier alnifolia (Nutt.) Nutt. ex M. Roem., Elsholtzia ciliata (Thunb.) Hylander, Syringa vulgaris L., Lepidium densiflorum Schrad., Lupinus polyphyllus Lindl., Lycopsis arvensis L., Medicago varia Martyn, Medicago sativa L., Mentha piperita L., Mentha gracilis Soll, Panicum miliaceum L., Papaver rhoeas L., Pastinaca sativa L., Ulmus laevis Pall., Viola arvensis Murray, representatives of the genera Oenothera, Xanthium and many others. The fourth group - ephemerophytes, includes 10 species that are known from individual finds, but currently do not naturalize on the territory of Kuzbass, in this regard, they disappear from the places of initial finds, but can appear as a result of repeated introduction again: Abutilon theophrasti Medikus, Avena sativa L., Bromus mollis L., Eruca sativa L., Helianthus annuus L., Papaver rhoeas L., Portulaca oleracea L., Vaccaria hispanica (Mill.) Rauschert. 
The analysis of the ranges of representatives of the adventive flora of Kuzbass allows us to determine the ways of penetration of these species into the territory of the region. The heterogeneous habitats of the Advents indicate that the alien species that have now become part of the flora of the higher vascular plants of Kuzbass were brought in from the most diverse parts of the world. Some of the species entered the territory of Kuzbass from various regions of the Mediterranean: Bromus mollis, Carduus acanthoides, Chorispora tenella (Pall.) DC., Erucastrum armoracioides, Grossularia reclinata, Reseda lutea, Syringa vulgaris. There are representatives of North American origin: Acer negundo, Ambrosia artemisiifolia, Aster novi-belgii L., Amelanchier spicata (Lam.) K. Koch, Cyclachaena xanthiifolia (Nutt.) Fresen., Helianthus annuus L., Solidago canadensis L., Lupinus polyphyllus Lindl., etc. The smallest group consists of Central American and South American species: Galinsoga ciliate (Raf.) Blake, Nicandra physalodes (L.) Gaertn.. There are representatives from Central and Central Asia: Elaeagnus angustifolia L., Malus domestica, Senecio dubitabilis. However, it should be noted that, in general, Advent species have wide ranges (pluregional, Palaearctic, Holarctic); for many of them, it is difficult to establish the initial range: Amaranthus blitoides, Armoracia rusticana, Buglossoides arvensis, Elodea canadensis, Echinochloa crusgalli, Epilobium pseudorubescens, Epilobium adenocaulon, Camelina microcarpa, Fumaria officinalis, Impatiens parviflora, Lepidium ruderale, Matricaria recutita, Malva pulchella, Medicago sativa, Mentha gracilis, Oenothera villosa, Sisymbrium loeselii.

Analysis of the life forms of apophytes, according to the classification of life forms of Raunkier, showed that among the alien species of Kuzbass in the first place are annuals, which experience an unfavorable period in the form of seeds - therophytes. There are 156 species of therophytes in the adventive fraction of the flora, the second place is occupied by hemicryptophytes, which preserve the buds of renewal at a time unfavorable for the growing season at the soil level, there are 62 species. In third place are cryptophytes, in which the buds of excitation are located in the soil or at the bottom of the reservoir, there are 26 species of them: Elodea canadensis, Potamogeton sarmaticus, Convallaria majalis, Iris pseudacorus, etc.

The classification of life forms of angiosperms by I.G. Serebryakova, which is based on ecological and morphological principles, divides the adventive species of Kuzbass into the following groups: herbaceous summer-green one-biennial tap-root monocarps: Ambrosia artemisiifolia, Chorispora tenella, Centaurea cyanus, Coreopsis tinctoria, Conyza canadensis; herbaceous summer-green perennial short-rhizome-brush-root polycarpics: Aster novi-belgii, Achillea setacea, Bellis perennis; herbaceous summer-green perennial taproot polycarpics: Lupinus polyphyllus, Malva moschata, Nepeta cataria; herbaceous summer-green perennial long-rhizome polycarpics: Centaurea phrygia, Mentha gracilis, Solidago serotinoides.

The ecological analysis of the adventive fraction of the flora of the Kemerovo region showed that among the invasive species in relation to the main ecological factors prevail: mesophytes - more than 78\% (moisture regime), non-petrophytes - more than $90 \%$ (stony substrate), mesotrophs - more than $92 \%$ (soil trophicity), heliophytes - about $90 \%$ (illumination).

\section{Conclusion}

As a result of the studies, it was found that the synanthropic fraction of the Kuzbass flora, consisting of adventive and apophyte species, accounts for about $18 \%$ of the total composition of the flora of vascular plants in the Kemerovo region (60 apophyte species, 244 - advent). Strengthening the process of invasion in modern phyto-systems is one of the major factors in changing the composition and structure of natural plant communities. And if the 
composition of apophytes is quite stable, then the species of Advent require close attention. As our research has shown, the composition of apophytes recorded in the territory of the Kemerovo region is rather heterogeneous, but we can note some peculiarities. By the time of introduction, eukenophytes predominate on the territory of the region - species introduced to Kuzbass in the XX century (more than $66 \%$ of the total composition of apophytes). According to the method of introduction, xenophytes predominate - alien species introduced by chance, together with cultural species or traffic flows with various cargoes (about 69\%). By the degree of naturalization, epecophytes predominate - species that spread over disturbed habitats and penetrate only segetal or ruderal communities (more than $80 \%$ ). The greatest concern is caused by agriophyte species that can be part of natural phytocenoses. Currently, their number is not high and amounts to $4 \%$, but they require close attention in order to undertake measures to eliminate the irreversible transformation of natural communities. It was also established that the ways of penetration of apophytes are also varied, but the most numerous group are Adventists with wide areas. The analysis of life forms and attitudes towards the main ecological factors shows the ability of alien species to adapt to the conditions existing in the region and stay for a long time on its territory. At present, the phenomena of transformation of the communities of ruderal and weed plants that have formed by now have been noticed due to the additional introduction of more aggressive species. It was assumed that the intensification of the invasion process is inevitable, and the strategies of the behavior of alien species are insufficiently studied, which determines the need for constant monitoring of alien species on the territory of Kuzbass. It is necessary to control the degree of naturalization of adventive species, for the timely identification of aggressive transformer species, in order to develop measures to combat agriophyte species.

\section{Acknowledgments}

This study was partially supported by the RFBR grant No. 20-44-420007r_a, and the state assignment on the topic "Assessment of the state and protection of floristic diversity under the influence of anthropogenic and technogenic factors in situ and ex situ", registration No. AAAA-A17-117041410053.

\section{References}

1. Report on the state and protection of the environment of the Kemerovo region - Kuzbass in 2019, 474 (2019)

2. A.N. Ermolaev, Russian-American company in Siberia and the Far East (1799-1971), 620 (2013)

3. I.E. Smelyansky, G.A. Pronkina, Key botanical territories of the Altai-Sayan eco-region: the experience of isolation, 260 (2009)

4. I.M. Krasnoborov, Bot. research on Siberia and Kazakhstan, 12, 134 (2006)

5. A.V. Kuminova, Vegetation of the Kemerovo region, 167 (1950)

6. A.N. Kupriyanov, S.S. Kazmina, A.A. Zverev, Bulletin of the Tomsk State University. Biology, 43, 66 (2018)

7. N.I. Naumenko, Flora and vegetation of the Southern Trans-Urals, 512 (2008)

8. V.V. Nikitin, Weed plants of the flora of the USSR, 452 (1983)

9. I.M. Krasnoborov, E. D. Krapivkina, M.N. Lomonosov, et al., Guide of plants of the Kemerovo region, 477 (2001)

10. Passport of the Kemerovo region - Kuzbass for 2019, http://ako.ru/

11. E.B. Rotkina, S.A. Sheremetova, Achievements of science and technology of AIC, 12, 73 (2011) 
12. M.M. Silantyeva, Flora of the Altai Territory: Analysis and History of Formation: Author's abstract, 35 (2008)

13. S.A. Sheremetova, R.T. Sheremetov, Basin of the Tom River (floristic and physicalgeographical features), 323 (2020)

14. A.L. Ebel, Abstract of the flora of the northwestern part of the Altai-Sayan province, 568 (2012)

15. S.A. Sheremetova, A.L. Ebel, T.E. Buko, Turczaninowia, 14, 65 (2011)

16. A.L. Ebel, A.N. Kupriyanov, T.O. Strelnikova, E.S. Ankipovich, E.M. Antipova, E.M. Antipova, T.E. Buko and et al., The Black Book of the Flora of Siberia, 440 (2016)

17. M. Kleunen, P. Petr, D. Wayne, et al., Ecology, 100(1), e02542 (2019)

18. A. F. Gulyaeva, N. N. Lashchinsky, N. N. Revushkin, et al., International Journal of Environmental Studies, 72(3), 527 (2015)

19. Important Plant Areas, http://www.plantaeuropa.org/

20. E.P. Kondratenko, E.A. Egushova, A. Starovoİtov, E. Starovoİtova, I.A. Sergeeva, E.B. Rotkina, Weed vegetation in spring wheat crops in the southeast of western siberia (on the example of Kemerovo region), 43 (2020)

21. S. A. Sheremetova, I. A. Khrustaleva, A. N. Kupriyanov, T. O. Strelnikova, G. I. Yakovleva, E. B. Rotkina, Botanical Journal, 106(7), 696 (2021) 